Komunike, Volume XI, No. 2, Desember 2019

\title{
MODERASI PENDIDIKAN PESANTREN BERBASIS PERJUMPAAN \\ DALAM BAYANG-BAYANG RADIKALISME \\ DI LOMBOK NUSA TENGGARA BARAT
}

\author{
Muhammad Fikri \\ Universitas Islam Negeri Mataram \\ muhammad_fikrie21@yahoo.com
}

\begin{abstract}
Abstrak
Moderasi pendidikan menjadi cita-cita semua manusia di dunia ini, karena itu yang paling dasar dalam diri manusia guna menciptakan perdamaian dalam dunia pendidikan yang tengah dibayang-bayangi oleh wacana radikalisme. Artikel ini pada dasarnya adalah penelitian lapangan dengan menggunakan teori bahasa atau komunikasi. Komunikasi atau dialog adalah bengkel tempat berlatih untuk menghilangkan permasalahan, untuk mengekspresikan kebenaran. Komunikasi atau dialog adalah institusi yang tidak bisa dihindari oleh setiap orang. Orang akan disebut sakit jika ia tidak pernah berinteraksi dengan sesama. Dalam berkomunikasi selalu ada hantaran bahasa saling kesefahaman. Begitu pentingnya bahasa dalam kehidupan kita sehari-hari hingga kita tidak menyadarinya, ia bagaikan nafas yang ketika hirup baru kita sadar akan pentingnya. Jika nafas kita sesak, maka kita tidak mampu berfikir, tidak banyak yang dapat kita perbuat karena kita hanya akan terfokus pada sesak itu sendiri. Kita cenderung tidak menghargai nafas sebelum kita merasakan sesak nafas. Pun demikian halnya dengan bahasa ketika kita berkomunikasi. Dan pendekatan penelitian ini peneliti menggunakan pendekatan fenomenologi dengan melihat fenomena-fenomena yang terjadi di tengah-tengah realitas pesantren. Dari hasil penelitian yang dilakukan bahwa pesantren sebagai saran pendidikan moderasi masih belum efektif karena masih terjadinya persainganpersaingan di semua level, dengan pola relasi dominan terbangun adalah menang atau kalah. Akibatnya ancaman perpecahan dan saling mencurigai terjadi di manamana, nyaris menjadi trend yang tak terbendungkan, terlebih dalam dunia pesantren yang nyaris dipengaruhi oleh bayang-bayang radikalisme.
\end{abstract}

Kata Kunci: Moderasi Pendidikan, Pesantren, Radikalisme. 


\section{A. Latar Belakang Masalah}

Moderasi pendidikan menjadi cita-cita semua manusia di dunia ini, karena itu yang paling dasar dalam diri manusia guna menciptakan perdamaian dalam dunia pendidikan yang tengah dibayang-bayangi oleh wacana radikalisme. Untuk menciptakan perdamaian, kemajuan, dan moderasi dalam dunia pendidikan kita harus membenci kekerasan atas nama apapun, baik itu agama dan kemanusiaan. Manusia harus saling menghargai, menerima, menghormati dan menjunjung tinggi nilai-nilai kemanusiaan. Maka dalam menciptakan moderasi, dibutuhkan jalur pendidikan pesantren berbasis sekolah perjumpaan, dalam menghadapi bayang-bayang radikalisme. Karena penulis percaya bahwa dengan jalur pendidikan kita bisa mengubah peradaban manusia di tengah-tengah kekrisisan yang dihadapi.

Moderasi pendidikan pesantren saat ini hanya sebatas wacana tanpa ada konsepsi yang jelas, terlebih lagi moderasi pendidikan disampaikan hanya sebatas da'wah yang di mana penyampaian pesan-pesan moderasi kenabian baru sebatas ceramah di atas podium semata dan tidak memiliki efek psikologis terhadap perubahan tindakan. Maka dari itu, moderasi pendidikan pesantren harus dilakukan pada ranah perjumpaan pembelajaran moral yang mengarah pada perubahan tindakan sehingga moderasi pendidikan pesantren berbasis sekolah perjumpaan harus berbasis recognitive learning ${ }^{1}$ yakni harus menyentuh aspek pembelajaran tindakan dalam menangkal bayang-bayang radikalisme.

Moderasi pendidikan pesantren sebagai arena perjumpaan dalam konteks ini diartikan sebagai perjumpaan hati dalam melaksanakan proses pendidikan. Karena

1 Rekognitif ini pertamakali dipopulerkan oleh M. Husni Muadz seorang linguist alumni Arizona university yang saat ini mengembangkan teori pembelajaran rekognitif. Teori pembelajaran rekognitif saat ini sedang diaplikasikan di Desa Perampuan dan 2020 lokasi di Lombok barat. Kata rekognitif ini sebenarnya diambil dari bahasa Inggris yakni recognition yang berarti pengakuan atau penghargaan. Akan tetapi dalam bahasa Indonesia recognition ini diterjemahkan menjadi rekognitif. Dan kata rekognitif dalam konteks pembelajaran diartikan menjadi suatu konsep pembelajaran yang berbasiskan kemanusiaan dalam membangun hubungan antar sesama tanpa syarat (intersubyektifitas), bagaimana menjadi damai, saling berterima dalam hidup bermasyarakat. Hubungan berterima tersebut merupakan nilai-nilai yang harus ada dalam pembelajaran rekognitif. Tidak hanya itu, rekognitif juga adalah pembelajaran yang mengedepankan nilainilai moral seperti perilaku baik, kepatuhan, kemaafan, sabar, berterima satu sama lain, dermawan dan lainlain. Disamping itu juga, pembelajaran rekognitif adalah suatu konsep pembelajaran non-material, dan selalu menyaratkan komunikasi verbal dan non verbal diantara semua makhluk untuk terus menjalin komunikasi dengan efektif. Dikatakan efektif karena ada perubahan diantara semua sistem sehingga untuk mewujudkan tujuan di atas maka nilai-nilai rekognitif atau perilaku-perilaku baik harus menjadi basis dalam setiap pembelajaran. M. Husni Muadz, Anatomi Sistem Sosial Rekonstruksi Normalitas Relasi Intersubyektivitas Dengan Pendekatan Sistem. (Mataram: Institut Pembelajaran Gelar Hidup IPGH, 2014), h. 60-70. 
perjumpaan selama ini telah direduksi hanya sebatas berjumpanya fisik semata, seperti perjumpaan-perjumpaan kita dengan seseorang yang tidak kita kenal di bus, kereta, pesawat dan perjumpaan-perjumpaan lainnya. Selama ini perjumpaan-perjumpaan yang ada belum dilihat memiliki tujuan instrinsik tunggal. Yang ada adalah pluralitas tujuan dari perjumpaanperjumpaan. Artinya perjumpaan tidak dilihat memiliki tujuan intrinsik, maka perjumpaan selama ini dilihat sebagai sarana dan secara transitif ini berarti para pelaku perjumpaan juga adalah sarana atau alat. Ini berarti secara tidak sadar kita memposisikan diri lebih rendah dari tujuan-tujuan perjumpaan. Akibatnya yang dominan dalam kehidupan sosial kita dalah persaingan-persaingan di semua level, dengan pola relasi dominana terbangun adalah menang atau kalah. Akibatnya ancaman perpecahan dan saling mencurigai terjadi di mana-mana, nyaris menjadi trend yang tak terbendungkan, terlebih dalam dunia pesantren yang nyaris dipengaruhi oleh bayang-bayang radikalisme. ${ }^{2}$

Dalam hal ini, Samuel Huntington pernah menulis buku berjudul The Clash of Civilization-Or, the West Against the Rest,

2 Husni Muadz, Pedagogi Hati: Praktek Positivitas Dalam Perjumpaan, (Mataram: IPGH, 2017), h. 5.
Foreign Affairs ${ }^{3}$ buku yang meramalkan bahwa di millenium ketiga ini akan ada benturan antar peradaban, diantaranya adalah peradaban Barat yaitu Amerika beserta sukutunya mewakili sistem kapitalisme dunia, peradaban Timur yaitu Rusia, Cina, Korea Utara beserta sekutunya mewakili sistem sosialisme komunisme dan terakhir peradaban Islam.

Seolah mengamini apa yang dikatakan Huntington, pada tahun 2001 Amerika Serikat mengobarkan perang global melawan terorisme ${ }^{4}$ sebagai reaksi terhadap aksi serangan pemuda Arab pembajak pesawat jet komersial Amerika Serikat terhadap gedung kembar World Trade Center dan Pentagon pada 11 September 2001. ${ }^{5}$ Akibat peristiwa tersebut melahirkan stigma negatif seperti radikalisme, terorisme menjadi sebuah identitas yang selalu dialamatkan kepada umat Islam terlebih lagi dunia pesantren. Amerika menjadi pemimpin mengomandoi seluruh dunia

3 Samuel P. Huntington, "The Clash of Civilization-Or, the West Against the Rest, Foreign Affairs"72 1993.

4 Sigma negatif teroris yang dimaksud Amerika Serikat adalah umat Islam. Akar persoalannya menurut Huntington terletak pada kenyataan bahwa Islam merupakan peradaban yang identik dengan kekerasan yang berbanding terbalik dengan barat yang toleran, egaliter dan demokrasi.

5 Meskipun sampai sekarang masih debatable siapa dalang di balik peristiwa tersebut, Amerika pun sampai sekarang belum mampu membuktikan apa yang dituduhkan. 
untuk memberangus jaringan teroris global seperti al-Qaeda yang diduga sebagai dalang yang bertanggung jawab atas peristiwa 11 September tersebut. ${ }^{6}$

Seluruh media di dunia termasuk media-media besar Nasional di Indonesia menayangkan peristiwa tersebut dan disaksikan rakyat Indonesia sembari mengutuk dalang yang bertanggung jawab atas terbunuhnya banyak orang pada 11 September tersebut. Menurut Noorhaidi Hasan, di Indonesia sendiri, luapan radikalisme dan aksi-aksi kekerasan atas nama jihad yang terjadi dalam satu dasawarsa terakhir telah mendorong Islam politik ke titik paling sentral dalam kajian kesarjanaan tentang dunia Islam. Istilah Islam politik terdistorsi menjadi begitu identik dengan radikalisme dan terorisme, hal ini tak lain karena istilah Islam politik telah jauh terseret ke dalam retorika yang

6 Islamophobia itu berlanjut dan mencapai punjaknya ketika Donald Trump memenangkan pemilu menggantikan Obama. Kebijakan Executive Order atau dikeluarkannya aturan melarang pendatang dari tujuh negara mayoritas muslim untuk memasuki Amerika. Kebijakan tersebut segera menyulut gelombang protes, bahkan kemarahan yang tidak saja warga muslim Amerika, akan tetapi juga masyarakat luas yang non muslim di negeri itu. Belum selesai sampai di sana gelombang protes pun terjadi di mana-mana, demonstrasi besar-besaran terjadi di titik-titik strategis seperti bandara internasional di berbagai kota Amerika Serikat. Dan pada akhirnya keputusan Executive Order itu dibatalkan oleh hakim tinggi Amerika meskipun Tramp melayangkan banding untuk kedua kalinya namun tetap ditolak. bergerak liar mengikuti logika perang global melawan terorisme. ${ }^{7}$

Berkaitan dengan hal di atas, ada beberapa catatan buram pada aspek radikalisme, di mana laporan yang ditulis Mohammad Zulfan Tadjoeddin dari United Nation Support Facility For Indonesian Recovery (UNSFIR) tahun 2002, menunjukkan jumlah kekerasan sejak 1998 melesat naik. Laporan itu berisi, di tahun itu, 124 insiden terjadi dengan korban tewas 1.343 orang. Dua tahun sebelumnya (1996), terjadi 8 insiden dengan jumlah korban tewas 227 orang. Pada tahun 1997, terjadi 15 insiden dengan 131 korban tewas. Setahun pasca Suharto jatuh (1999), jumlah insiden masih terus menanjak, jumlahnya mencapai 300 insiden dengan 1.813 korban tewas. Pada tahun 2000, menjadi 408 insiden dengan 1.617 korban. Sedangkan pada tahun 2001 menjadi 233 insiden dengan korban terwas 1.065 orang. ${ }^{8}$

Berdasarkan hasil riset berjudul "research on motivation and root cause of terrorism: terhadap 110 pelaku tindak terorisme yang dilakukan oleh The

7 Noorhaidi Hasan, Islam Politik Di Dunia Kontemporer; Konsep, Geneologi, dan Teori, (Yogyakarta: Suka Press, 2012), h. 1.

${ }^{8}$ Zuly Qodir, "Peran Ulama Mempertahankan NKRI dan Ke-Indonesia-an", Makalah Disampaikan pada Seminar Nasional "Peran Ulama Menyelamatkan Indonesia" dalam rangka Hut Fakultas Dakwah, 11/11.2014. 
Indonesian research team; Kementerian Luar Negeri, INSEP dan Densus 88 pada tahun 2012 menemukan bahwa berdasarkan tingkat usia para pelaku terorisme tersebut sangat beragam. Usia kurang dari 21 tahun sebanyak $11,8 \%$, usia 21-30 tahun sebanyak $47,3 \%$, usia 31-40 tahun sebanyak $29,1 \%$, dan usia lebih dari 40 tahun sebanyak 11,8 $\%$. Sedangkan pelaku teroris berdasarkan tingkat pendidikan menunjukan bahwa lulusan SD sebanyak 3,6 \%, lulusan SMP sebanyak 10,9 \%, lulusan SMA mendominasi dangan angka 63,6 \%, sementara DO universitas sebanyak 5,5\% dan lulusan Universitas sebanyak $16,4 \%{ }^{9}$

Sementara itu sebuah survey yang dilakukan oleh FISIP UIN Hidayatullah Jakarta pada tahun 2011 yang bertemakan "survey radikalisme sosial-keagamaan Mahasiswa UIN/IAIN" dilakukan di 7 provinsi meliputi Jakarta, Yogyakarta, Makasar, Surabaya, Banjarmasin, Sumatera Utara dan Padang. Dengan mengajukan sebuah pertanyaan, Jihad dengan motif balas dendam terhadap yang menyerang Islam?, hasilnya adalah sebagai berikut; Sebanyak 23,6 \% setuju, 67,9 \% tidak setuju, selebihnya tidak merespon. Jihad dengan perang mengangkat senjata sebanyak $37,1 \%$

${ }^{9}$ M. Arifin Zuhdi, Kontra Radikalisme \& Terorisme "Counter Terhadap Ideology Radikal", (Mataram: Sanabil, 2016), h.1. setuju, dan 55, 2\% tidak setuju. Jihad dengan mengorbankan nyawa, 28,8 \% menyatakan setuju, dan $65,8 \%$ tidak setuju. Jihad dengan menggunakan kekerasan 26,7 $\%$ setuju, $68,4 \%$ tidak setuju dan selebihnya tidak bersikap. ${ }^{10}$

Baru-baru ini Wahid Foundation bekerja sama dengan LSI melansir sebuah survei. Suvei Nasional yang melibatkan rensponden dari 34 Provinsi di mana survey ini memunculkan sebuah data dan fakta yang mengejutkan bahkan mengkhawatirkan: Mayoritas muslim Indonesia (72\%) "menolak" tindakan radikal. 7,7 \% yang "bersedia" melakukan tindakan radikal bila ada kesempatan dan 0,4 yang "pernah" melakukan tindakan radikal.

Temuan di atas tentu menjadi daftar panjang bagaimana intoleransi tumbuh subur di hati rakyat Indonesia. Salah satu alasan mengapa diskursus tentang hubungan antara agama dengan negara memperoleh porsi yang begitu besar di Indonesia, tidak lain karena Indonesia terletak di wilayah pada karakter demografis Asia Tenggara. Pada Tahun 2014 jumlah populasi mencapai 250 juta Jiwa, di mana $87 \%$ beragama Islam, ${ }^{11}$

${ }^{10}$ Ibid., h. 2.

11 Tahun 2014, Indonesia tercatat sebagai empat negara dengan jumlah penduduk terbesar di dunia. sepuluh negara dengan jumlah penduduk 
Indonesia menjadi negara dengan mayoritas penduduk Muslim terbesar di dunia dengan jumlah muslim lebih dari 200 juta jiwa. Namun alasan yang jauh lebih mendasar mengapa isu-isu itu sangat menonjol dalam kajian-kajian mengenai Indonesia terletak pada perubahan tiba-tiba orientasi politik di negara itu, dan tantangan-tantangan yang dibawanya pada masalah toleransi agama, kebebasan sosial, dan kewarga-negaraan. ${ }^{12}$

Berangkat dari hal tersebut tentu moderasi pendidikan pesantren menjadi sebuah tawaran sekaligus tantangan tersendiri dalam menjalankannya, karena berada di bawah bayang-bayang radikalisme. Namun hal ini bukan menjadi halangan bahwa moderasi pendidikan tidak bisa tumbuh di tengah-tengah masyarakat pesantren, meskipun masih dibayangi oleh radikalisme.

terbesar adalah pertama, china 1.355.692.576. kedua, India 1.236.344.631, ketiga, Amerika Serikat 318.892.103, keempat, Indonesia 253.609.643; kelima, Brasil 202.656.788. Keenam, Pakistan 196.174.380; ketujuh, Nigeria 177.155.754; kedelapan, Bangladesh 166.280. 712; kesembilan Russia 142.470.272; kesepuluh Jepang 127.103.388. (http://finance.detik.com/read/2014/03/06/134053/25 17461/4/negara-dengan-penduduk-terbanyak-didunia-ri-masuk-4-besar. 06/03/2014 15:04 WIB, diunduh Jum'at 18 September 2014)

12 Robert W. Hefner, dalam buku Mengelola Keragaman dan Kebebasan Beragama di Indonesia: Sejarah, Teori dan Advokasi, Program Studi Agama dan Lintas Budaya (Center for Religious and Crosscultural Studies) Sekolah Pascasarjana, Universitas Gadjah Mada, 2014. h. 32.
Dalam aspek moderasi pendidikan pesantren berbasis sekolah perjumpaan harus dilakukan adalah redifinisi konsep perjumpaan dan memulai normalisasi praktek-praktek perjumpaan dalam institusi pendidikan yang dirancang sesuai tujuan intrinsik dari perjumpaan itu sendiri. Institusi pembelajaran yang diperlukan tidak bisa didapatkan di dalam institusi institusi perjumpaan yang ada, karena mindset tujuan perjumpaan masih bersifat instrumental. Oleh karenanya, diperlukan institusi pembelajaran yang khusus dirancang untuk perbaikan praktek-praktek perjumpaan. Institusi tersebut adalah semacam bengkel perjumpaan, di mana setiap bengkel memiliki komunitas pembelajar yang memiliki komitmen untuk bersama-sama berlatih mempraktekkan kebaikan-kebaikan dalam perjumpaan. Institusi pembelajaran perjumpaan dengan tujuan seperti ini bisa dikatakan sebagai moderasi pendidikan pesantren sebagai tempat perjumpaan, karena apabila moderasi pendidikan pesantren pada dimensi sekolah perjumpaan ini belangsung, maka akan melahirkan emergence keberterimaan hati. ${ }^{13}$

Di samping itu, moderasi pendidikan pesantren berbasis sekolah perjumpaan membutuhkan emotioning dan languaging

\footnotetext{
${ }^{13}$ Ibid., h. 6.
} 
Komunike, Volume XI, No. 2, Desember 2019

yang beroperasi dalam perjumpaanperjumpaan, yang berarti normativitas dari ke duanya juga beroperasi dalam perjumpaan perjumpaan. Apa tujuan perjumpaan? Selama ini perjumpaan dilihat memiliki tujuan sesuai yang dikehendaki oleh para pihak yang berjumpa. Perjumpaan adalah sarana agar dialog moderasi pendidikan pesantren bisa berlansung atau bisa dirumuskan. Jadi tujuan perjumpaan bisa berbeda beda; tujuan perjumpaan bisa tidak sama antara yang satu dengan yang lainnya.

Moderasi pendidikan pesantren berbasis sekolah perjumpaan yang bisa ditawarkan dalam tulisan ini adalah gagasan bahwa semua jenis perjumpaan memiliki hanya satu tujuan yakni untuk memperjumpakan dan mempersatukan hati. Yang lainnya hanya dianggap sebagai tujuan sebenarnya bukan tujuan tetapi salah satu indikator dari kebehasilan perjumpaan. Aktivitas yang dimiliki perjumpaan untuk mencapai tujuan intrinsiknya ada dua: sikap batin (emotioning) dan tindakan lahir, yaitu tindakan berbahasa (yang nantinya akan melahirkan tindakan tindakan lainnya yang non-bahasa). Moderasi pendidikan pesantren berbasis sekolah perjumpaan dalam hal ini sebagai lembaga untuk mempersatukan hati, maka sarana yang digunakan adalah positivitas emotioning dan positivitas tindakan berbahasa. Memilih negativitas dari keduanya akan membuat hati saling menjauh. Antara sarana dan tujuan harus sesuai, dan sarana yang baik adalah sarana yang paling efektif untuk mencapai tujuan. Ini tuntutan rasionalitas biasa. Bila hubungan baik dengan sesama adalah tuntutan eksistensial, maka masuk akal kenapa perjumpaan, emotioning, dan tindakan ilokusi adalah fenomena yang tidak bisa dihindari dalam hidup manusia, karena ketiganya adalah syarat wajib yang harus ada untuk tujuan konektivitas hati, tetapi bukan syarat cukup. Syarat cukup adalah beroperasinya positivitas yang terkait dengan emotioning dan tindakan tindakan ilokusi dalam setiap pembelajaran di pesantren. ${ }^{14}$

\section{B. Metode Penelitian}

Metode penelitian sangat penting dalam suatu penelitian, karena metode penelitian merupakan cara-cara untuk mengetahui sesuatu. ${ }^{15}$ Maka dari itu, agar penelitian ini dapat diajukan dan dapat dipertanggungjawabkan secara ilmiah dan akademis, maka diperlukan metodologi yang relevan yang mampu menganalisis berbagai

\footnotetext{
${ }^{14}$ Ibid., h. 4-5.

${ }^{15}$ Nyoman Kutha Ratna, Metodologi Penelitian Kajian Budaya dan Ilmu Humaniora Pada Umumnya, (Yogyakarta: Pustaka Pelajar, 2010), h. 40 .
} 
sumber data yang di peroleh khususya dalam konteks moderasi pendidikan pesantren.

Dalam penelitian ini peneliti menggunakan pendekatan fenomenologi dengan melihat fenomena-fenomena yang terjadi di tengah-tengah realitas pesantren. Dan jenis penelitian ini adalah penelitian lapangan (Field Research), yang bersifat deskriptif analitik, yang bertujuan untuk mendeskripsikan apa-apa yang saat ini berlaku, menganalisa dan menginterpretasikan kondisi-kondisi yang sekarang ini terjadi atau yang ada. ${ }^{16}$ Dengan kata lain penelitian deskriptif bertujuan untuk memperoleh informasi-informasi mengenai keadaan saat ini, dan melihat antara variabel-variabel yang ada. Penelitian ini tidak menguji hipotesa atau tidak menggunakan hipotesa, melainkan hanya mendeskripsikan informasi apa adanya sesuai dengan variabel-variabel yang diteliti. $^{17}$

Kemudian metode analisis untuk mengkaji moderasi pendidikan pesantren dalam dalam memberikan tawaran baru baik metodologi dan konsep ini tidak membicarakan besar kecilnya sampel sebagai informan. Tujuannya seperti jumlah

16 Moleong, Metode Penelitian Kualitatif (Bandung: Remaja Rosdakarya, 1994), h. 224.

Mardalis, Metode Penelitian, (Jakarta:PT.Bumi Aksara, 2004), h.26. sampel ditentukan dengan mempertimbangkan informasi-informasi yang diperlukan. Jumlah informan akan ditambah jika ingin memperluas informasi, namun jika tidak ada lagi informasi atau sudah mulai ditemukan pengulanganpengulangan informasi (data jenuh), maka penarikan para informan sudah harus dilakukan. $^{18}$

\section{Teknik Pengumpulan Data}

Dalam pengumpulan data, ada beberapa langkah yang digunakan oleh peneliti yakni:

a. Observasi

Observasi merupakan teknik pengumpulan data terhadap hal-hal yang diteliti dengan terjun langsung ke pesantren di wilayah Lombok NTB untuk melihat dan mengamati aktivitas sehari-hari pembelajaran di pesantren. Dan juga melihat bagaimana tingkat interaksi antar santri dan mendengarkan pembicaraan secara langsung maupun tidak langsung yang sesuai mengenai tema moderasi pendidikan pesantren.

b. Wawancara

Disamping observasi secara langsung, pengumpulan data juga dilakukan dengan tekhnik wawancara bebas terpimpin kepada narasumber, bebas dalam arti tidak formal dan kaku. Terpimpin dalam arti tidak

\footnotetext{
${ }^{18}$ Moleong, Metode Penelitian ..., h. 225.
} 
Komunike, Volume XI, No. 2, Desember 2019

hanya membiarkan proses wawancara mengalir apa adanya, akan tetapi terarah terhadap kajian pada penelitian ini. Sedangkan para narasumbernya adalah: Pertama, para tuan guru. Kedua, santri. Ketiga, masyarat di luar pesantren. Hal ini penting, karena mereka yang memberikan legitimasi mengenai tingkat moderasi pendidikan pesantren pada dimensi sekolah perjumpaan dalam menangkal bayangbayang radikalisme di tengah-tengah pesantren. Keempat, kalangan akademisi, dalam hal ini dosen, dan mahasiswa yang memiliki opini berkaitan dengan penelitian yang dilakukan.

c. Dokumentasi

Dokumentasi tentu sangat penting dalam penelitian ini untuk melihat data-data yang berkaitan dengan pesantren, seperti penelusuran atas informasi-informasi, bukubuku di lingkungan peantren sebagai bahan literasinya, majalah, surat kabar, dokumen arsip-arsip, serta data-data pendukung lainnya.

\section{Metode Analisis Data}

Analisis data merupakan hal yang terpenting dalam metode ilmiah, karena dengan analisislah data tersebut dapat berguna dalam memecahkan masalah penelitian. Metode analisis data yang digunakan dalam penelitian ini yaitu analisis data kualitatif berupa kata-kata bukan berupa angka-angka yang di susun dalam tema yang luas. Analisis data adalah proses menyusun data agar dapat ditafsirkan. Ditafsirkan atau interpretasi artinya memberikan makna kepada analisis untuk menjelaskan pola atau kategori mencari hubungan antar berbagai kosep. ${ }^{19}$ Analisis data menurut Sugiyono dalam Bogdan menyatakan:

Data analysis is the process of systematically searching and arranging the interview trancripts, field notes, and other materials that you accumulate to increase your own understanding of them and to enable you to present what you have discovered to others. ${ }^{20}$

Analisis data secara kualitatif yang berkaitan dengan hasil observasi dan wawancara langsung dilapangan guna mendapatkan pemahaman secara mendalam terhadap fenomena yang muncul dari pendataan lapangan. Analisis selanjutnya yakni berkaitan dengan merumuskan program-program moderasi pendidikan pesan dalam menangkal bayang-bayang radikalisme.

\footnotetext{
${ }^{19}$ Elvinaro Erdianto, Metodologi Penelitian Untuk Public Relations Kuantitatif dan Kualitatif, (Bandung: Simbiosa Rekatama Media, 2010), h. 215. ${ }^{20}$ Sugiyono, Metode Penelitian Kombinasi, (Bandung: Alfabeta, 2013), h. 332.
} 


\section{Landasan Konseptual}

Untuk memperkuat penelitian ini, penulis menggunakan teori bahasa dalam mengantarkan bagaimana konsep moderasi pendidikan pesantren. Dalam menciptakan moderasi pendidikan pesantren dalam dimensi perjumpaan dalam menghadapi bayang-bayang radikalisme, maka dalam perjumpaan membutuhkan bahasa, karena segala hal dalam rangka saling berterima harus dimulai dari bahasa, sehingga semua embrio yang berkaitan dengan moderasi pendidikan pesantren tindakannya berpusat pada bahasa.

Bahasa begitu penting, karena segala hal dalam rangka saling berjumpa dimulai dari bahasa, oleh karena itu segala embrio yang berkaitan dengan moderasi pendidikan pesantren terpusat pada tindakan bahasa. Semua orang memiliki bahasa, dan semua orang mampu berbahasa. Jika bahasa mampu menyatukan segala sesuatu, maka pendidikannya dimulai dari bahasa, sehingga tidak mungkin terjadi persatuan jika tidak ada pertemuan. Kemudian berbahasa adalah syarat kedua dalam moderasi pendidikan pesantren. Jadi perjumpaan adalah syarat pertama persatuan dan bahasa adalah syarat kedua. Karena dengan bahasalah kita bisa mengerti dan memahami isi hati dan pikiran kita, bukan dengan sentuhan atau rabaan. Bahasa adalah keahliaan khusus yang dimiliki oleh manusia, karena kemampuannya untuk melahirkan output yang tidak terbatas jumlahnya. ${ }^{21}$

Komunikasi atau dialog adalah bengkel tempat berlatih untuk menghilangkan permasalahan, untuk mengekspresikan kebenaran. Komunikasi atau dialog adalah institusi yang tidak bisa dihindari oleh setiap orang. Orang akan disebut sakit jika ia tidak pernah berinteraksi dengan sesama. Dalam berkomunikasi selalu ada hantaran bahasa saling kesefahaman. Begitu pentingnya bahasa dalam kehidupan kita sehari-hari hingga kita tidak menyadarinya, ia bagaikan nafas yang ketika hirup baru kita sadar akan pentingnya. Jika nafas kita sesak, maka kita tidak mampu berfikir, tidak banyak yang dapat kita perbuat karena kita hanya akan terfokus pada sesak itu sendiri. Kita cenderung tidak menghargai nafas sebelum kita merasakan sesak nafas. Pun demikian halnya dengan bahasa ketika kita berkomunikasi.

Bayangkan ketika bahasa dalam berkomunikasi diekploitasi seenaknya hingga berujung ketika bahasa itu terganggu kemudian menciptakan konflik, namun

\footnotetext{
${ }^{21}$ Sahabudin, wawancara 26 September 2015.
} 
dengan jalan dialoglah kebenaran tertinggi itu dapat kita temukan. ${ }^{22}$

Merujuk bahasa sebagai suatu tindakan, bahwa bahasa mulai di perkenalkan pada tahun 60-an, bahasa adalah tindakan dengan berkata-kata. Jika Tuhan bisa menciptakan dunia dengan bahasa "kun fayakun" maka terciptalah, dan manusia juga bisa menciptakan kemerdekaan dengan bahasa, kita bisa menciptakan perceraian dengan bahasa, pernikahan dengan bahasa, kita bisa menyatukan umat dengan bahasa, kita bisa menyatakan perasaan dengan bahasa, perkelahian dengan bahasa, jadi peran bahasa adalah sangat sentral. Semua orang punya bahasa, semua orang mampu berbahasa. Jika bahasa mampu menyatukan segala sesuatu, maka moderasi pendidikan pesantren dimulai dari bahasa. Sehingga tidak mungkin terjadi persatuan jika tidak ada bahasa dan pertemuan. Seperti yang dikatakan di atas berbahasa adalah syarat kedua dalam pendidikan pesantren, karena syarat pertama adalah perjumpaan, jadi

22 Akan tetapi kepercayaan terutama yang berkaitan dengan dunia keseharian, kita bisa salah bisa benar, maka untuk bisa memastikan bahwa opini kita benar atau salah, kita bisa mengujinya dalam dialog. ... kita harus berangkat dari apa yang kita anggap benar, tetapi untuk memastikan kebenarannya kita harus terbuka terhadap kemungkinan ada yang lebih benar yang hanya bisa diketahui melalui dialog. Kita berangkat dari kebenaran menuju kebenaran yang lebih tinggi, yaitu kebenaran intersubjektif. M. Husni Muadz, Anatomi Sistem... h. 239. perjumpaan dan bahasa adalah syarat sebagai pendidikan pesantren.

Dalam konteks bahasa sebagai tindakan hal ini senada seperti yang dikatakan oleh John Austin dalam speech acts. Dalam speech acts terdapat tindakan berbahasa terdiri dari tiga bagian: locutionary act, illocutionary act dan perlocutionary act. Komponen pertama, locutionary act (LA), merupakan tindakan mengatakan suatu makna tertentu. Suatu ucapan yang menyampaikan "isi bahasa" yang bermakna pada dirinya, sebagai contoh: “Ada anjing di kebun". Atau dengan kata lain (LA) adalah sesuatu yang mana phonetic, phatic, dan rhetic act merupakan sebagai elemen inti. Hubungan antar ketiga elemen-elemen ini bersifat hirarkis yang bergantung satu sama lain. Dengan kata lain, kita bisa menghasilkan phatic act melalui phonetic act, tapi tidak sebaliknya. Terkait dengan rhetic act, Austin menegaskan dua poin penting yakni: sebuah tipe tindakan berbahasa tidak langsung dan tindakan yang bergantung pada sense dan reference.

Komponen kedua tindakan berbahasa adalah illocutionary act (IA). Dihasilkan ketika melakukan locutionary act, yakni cara menghasilkan locutionary act bisa menjadi cara melakukan illocutionary act. Atau dengan kata lain, illocutionary act 
mengucapkan suatu kalimat dengan menggunakan suatu daya force yang khas. Karena kita menggunakan illocutionary force itu ucapan kita menjadi: perjanjian, perintah, pernyataan, vonis, dan lain sebagainya. Elemen kedua ini merupakan unit yang telah menjadi perdebatan tentang karakternya. Beberapa pakar percaya bahwa illocutionary act sebagai tindakan yang berbasis konventional atau aturan. Sebaliknya, yang lain percaya itu didasari oleh niat atau dugaan. Dengan perbedaan pandangan ini telah menghasilkan dua aliran dalam membangun teori tindakan berbahasa yakni aliran yang berbasis aturan atau konvensi dan yang berbasis inferensi. Sebagai contoh, klasifikasi tindakan berbahasa (commissive, assertive $\mathrm{dsb}$ ) ada yang berdasarkan illocutionary force dan propositional attitude.

Elemen ketiga tindakan berbahasa adalah perlocutionary act (PA). Ini merupakan unit terkait dengan konsekwensi dari tindakan berbahasa. Bagi Austin perlocutionary act adalah ucapan kita dapat mengakibatkan suatu efek psikologis pada para pendengar: mereka setuju, merasa puas, takut, dan lain sebagainya. Austin menyangka bahwa dalam setiap ucapan paling sedikit terkandung suatu locutionary act, dan suatu illocutionary act. Kadang- kadang juga suatu perlocunionary act. Tidak hanya itu, menurut Austin, illocutionary act dan perlocutionary act berbeda dalam hal konsekwensi yang dilahirkan. IA memiliki properti securing uptake, taking effect dan inviting response. Securing uptake terkait dengan makna dan force dari lokusi yang menjadi indikator sukses tidaknya IA. Dengan kata lain, hal penting dalam IA adalah pendengar atau pembicara memahami makna dan force yang dimiliki IA. Taking effect melahirkan states of affair seperti kepercayaan, keinginan, hasrat dsb. Inviting response merupakan tindakan kedua atau selanjutnya dari pembicara dan pihakpihak terkait dalam komunikasi. Ketiga properti (Securing uptake, Taking effect, Taking effect (inviting response)) ini bersifat binding bagi IA. Sedangkan PA berbeda dengan IA dalam hal cara unconventional untuk mencapai dan mengasilkan akibat atau dampak dari komunikasi.

Seperti yang dikatakan di atas bahwa moderasi pendidikan pesantren tidak bisa lepas dari bahasa. Karena moderasi pendidikan pesantren merupakan pembelajaran yang berkatian dengan bagaimana menerapkan nilai kebenaran dalam ranah tindakan manusia. Pembelajaran selama ini telah terjadi ketidak 
Komunike, Volume XI, No. 2, Desember 2019

seimbangan antara pemahaman, dan perilaku (moralitas) karena pembelajaran formal baru menyentuh ranah pengetahuan/kognisi saja, tak perlu di pungkiri lagi output dari sekolah formal, termasuk sekarang ini adalah orang-orang yang pintar tapi bukan orang-orang baik. Maka untuk menjawab hal tersebut moderasi pendidikan pesantren memberikan jalan keluar dan hal-hal yang harus dilakukan dalam setiap institusi pendidikan.

Dalam moderasi pendidikan pesantren bahwa institusinya adalah perjumpaan itu sendiri dan yang menjadi sarananya adalah pesantren, dan pembelajarannya terjadi ketika berkomunikasi atau dialog. Komunikasi adalah tempat berlatih untuk menghilangkan paksaan dalam mengekspresikan kebenaran. Komunikasi adalah institusi yang tidak bisa dihindari oleh setiap orang karena semua orang membutuhkan komunikasi dalam menjalin suatu hubungan tanpa syarat. Komunikasi adalah pendukung dalam sistem sosial moderasi pendidikan pesantren, karena tanpa komunikasi/bahasa maka dalam suatu kelompok masyarakat belum bisa dikatakan masyarakat yang komunikatif. Komunikasi juga sebagai tujuan manusia untuk memahami dan menginterpretasikan fenomena sekelilingnya. Komunikasi/bahasa merupakan modal sosial yang sangat penting yang dimiliki manusia untuk berinteraksi, memelihara, mengukuhkan, dan mengkonversi untuk saling mengubah, karena dalam bahasa terdapat unsur moralitas dalam menciptakan tindakan bersama collective action.

Dalam pandangan interaksionisme simbolik komunikasi atau interaksi itu penting sebagai tujuan untuk mengubah apapun dalam sistem sosial kemanusiaan. Tidak hanya itu komunikasi yang terjalin diantara semua individu adalah komunikasi untuk mencari kebenaran intersubyektif. Dan komunikasi yang terjalin diantara semua memang menjadi tujuan, karena komunikasi pada dasarnya adalah tujuan, bukan sarana. Bila komunikasi adalah sarana, maka partisipan atau elemen-elemen yang terlibat di dalamnya adalah sarana juga. Komunikasi adalah tindakan primer dari komponen sistem sosial. Dan setiap koordinasi sosial adalah konsekuensi dari komunikasi. Apabila semua ini terjadi dalam ranah tujuan maka komunikasi akan menghasilkan tindakan sosial social action, tindakan sosial ini terjadi karena konsekwensi dari komunikasi.

Moderasi pendidikan pesantren ini juga berbasiskan kesadaran individu untuk terus menjalin komunikasi dengan cara terbuka 
sehingga proses saling keberterimaan tanpa syarat. Dengan kata lain, membangun hubungan secara tulus. Di samping itu juga, setiap status sosial sebisa mungkin untuk dilepaskan agar otoritas-otoritas tertentu tidak berperan dalam proses pembelajaran agar tidak tercipta iam my position. Tujuan untuk melepaskan status-status tersebut karena moderasi pendidikan pesantren berkaitan dengan pembelajaran tanpa syarat dan tendensi tertentu (imperative kategoris). Oleh karenanya, moderasi pendidikan pesantren mengindikasikan pembelajaran seumur hidup long life learners dan harus terus dilakukan oleh semua orang. Karena selama ini moderasi pendidikan pesantren seringkali dilupakan padahal pembelajaran ini merupakan basis dari semua pembelajaran, karena apabila ini berjalan dengan baik maka produk-produk pembelajaran akan cepat tercipta. Produkproduk tersebut seperti pintar, menghargai, jujur, bermoral dan bertanggungjawab. Mengapa demikian, karena basis pembelajarannya berjalan dengan efektif, karena manusianya yang dibangun berdasarkan asas kemanusiaan.

\section{Penutup}

Moderasi pendidikan menjadi citacita semua manusia di dunia ini, karena itu yang paling dasar dalam diri manusia guna menciptakan perdamaian dalam dunia pendidikan yang tengah dibayang-bayangi oleh wacana radikalisme. Untuk menciptakan perdamaian, kemajuan, dan moderasi dalam dunia pendidikan kita harus membenci kekerasan atas nama apapun, baik itu agama dan kemanusiaan. Manusia harus saling menghargai, menerima, menghormati dan menjunjung tinggi nilai-nilai kemanusiaan. Dari hasil penelitian ini menunjukkan bahwa moderasi pendidikan pesantren sebagai arena perjumpaan bisa dilaksanakan dalam proses pendidikan. Karena perjumpaan selama ini telah direduksi hanya sebatas berjumpanya fisik semata, seperti perjumpaan-perjumpaan kita dengan seseorang yang tidak kita kenal di bus, kereta, pesawat dan perjumpaanperjumpaan lainnya. Selama ini perjumpaanperjumpaan yang ada belum dilihat memiliki tujuan instrinsik tunggal. Yang ada adalah pluralitas tujuan dari perjumpaanperjumpaan. Artinya perjumpaan tidak dilihat memiliki tujuan intrinsik, maka perjumpaan selama ini dilihat sebagai sarana dan secara transitif ini berarti para pelaku perjumpaan juga adalah sarana atau alat. Ini berarti secara tidak sadar kita memposisikan diri lebih rendah dari tujuan-tujuan perjumpaan. Akibatnya yang dominan dalam kehidupan sosial kita dalah 
Komunike, Volume XI, No. 2, Desember 2019

persaingan-persaingan di semua level, dengan pola relasi dominan terbangun adalah menang atau kalah. Akibatnya ancaman perpecahan dan saling mencurigai terjadi di mana-mana, nyaris menjadi trend yang tak terbendungkan, terlebih dalam dunia pesantren yang nyaris dipengaruhi oleh bayang-bayang radikalisme.

\section{Daftar Pustaka}

(http://finance.detik.com/read/2014/03/06/13 4053/2517461/4/negara-dengan-

penduduk-terbanyak-di-dunia-rimasuk-4-besar. 06/03/2014 15:04 WIB, diunduh Jum'at 18 September 2014)

Elvinaro Erdianto, Metodologi Penelitian Untuk Public Relations Kuantitatif dan Kualitatif, (Bandung: Simbiosa Rekatama Media, 2010)

Husni Muadz, Pedagogi Hati: Praktek Positivitas Dalam Perjumpaan, (Mataram: IPGH, 2017)

M. Arifin Zuhdi, Kontra Radikalisme \& Terorisme "Counter Terhadap Ideology Radikal", (Mataram: Sanabil, 2016)

M. Husni Muadz, Anatomi Sistem Sosial Rekonstruksi Normalitas Relasi Intersubyektivitas Dengan Pendekatan Sistem. (Mataram:
Institut Pembelajaran Gelar Hidup IPGH, 2014)

Mardalis, Metode Penelitian, (Jakarta:PT.Bumi Aksara, 2004)

Moleong, Metode Penelitian Kualitatif (Bandung: Remaja Rosdakarya, 1994)

Noorhaidi Hasan, Islam Politik Di Dunia Kontemporer; Konsep, Geneologi, dan Teori, (Yogyakarta: Suka Press, 2012)

Nyoman Kutha Ratna, Metodologi Penelitian Kajian Budaya dan Ilmu Humaniora Pada Umumnya, (Yogyakarta: Pustaka Pelajar, 2010)

Robert W. Hefner, dalam buku Mengelola Keragaman dan Kebebasan Beragama di Indonesia: Sejarah, Teori dan Advokasi, Program Studi Agama dan Lintas Budaya (Center for Religious and Cross-cultural Studies) Sekolah Pascasarjana, Universitas Gadjah Mada, 2014.

Samuel P. Huntington, "The Clash of Civilization-Or, the West Against the Rest, Foreign Affairs"72 1993.

Sugiyono, Metode Penelitian Kombinasi, (Bandung: Alfabeta, 2013)

Zuly Qodir, "Peran Ulama Mempertahankan NKRI dan Ke-Indonesia-an”, 
Komunike, Volume XI, No. 2, Desember 2019

Makalah Disampaikan pada

Seminar Nasional "Peran Ulama

Menyelamatkan Indonesia" dalam

rangka Hut Fakultas Dakwah,

11/11.2014. 